\title{
KLASIFIKASI WAKAF PRODUKTIF MENGGUNAKAN ALGORITMA ID3 PADA SISTEM INFORMASI ASET DAN KEHARTABENDAAN MAJELIS WAKAF YOGYAKARTA
}

\author{
Muhammad Munsarif \\ Program Studi Informatika, Universitas Muhammadiyah Semarang \\ Jl. Kedungmundu Raya No 18, Semarang \\ m.munsarif@unimus.ac.id
}

\begin{abstract}
Productive Waqf is one of the waqf management programs developed in the modern era to improve the Islamic economy. The large number of waqf land received by nazir from year to year causes the management of waqf to be more complicated. This is caused by the lack of financial support and based on data from the ministry of religion in April 2020 the area of waqf land is 50,260.89 Ha. The waqf information system that has been developed has not been able to be a solution to the problems of waqf land management. Muhammadiyah which is the oldest Islamic organization that has succeeded in making many charitable efforts using waqf still not able to overcome the existing problems. The amount of waqf that is owned by Muhammadiyah requires an analysis to make a classification of productive and non-productive endowments that can provide information to make decisions in the management of endowment management on an ongoing basis. In this research, the ID3 algorithm is used for waqf classification which can show productive and non-productive categories using data derived from Muhamamdiyah Asset Information System in the Yogyakarta region. The results of the study provide recommendations that are shown in the decision tree produced by ID3 so that it can be concluded that for the management of waqf it is necessary to group and classify productive and non-productive land to create a professional endowment management plan.
\end{abstract}

Keywords: Decision Support System, ID3 Algorithm, Data Mining, Waqf information system, Productive Waqf, Muhammadiyah, Rapidminner.

\begin{abstract}
Wakaf produktif menjadi salah satu program pengelolaan wakaf yang dikembangkan di era modern dengan tujuan untuk meningkat perekonomian umat islam.Besarnya Jumlah wakaf tanah yang diterima oleh para nadzir dari tahun ke tahun menyebabkan pengelolaan wakaf menjadi lebih rumit.Hal ini di sebabkan tidak adanya dukungan pembiayaan dan pengembangannya.Berdasarkan data dari kementerian agama pada April 2020 luas tanah wakaf 50.260.89 Ha .Sistem informasi wakaf yang telah dikembangkan belum mampu menjadi solusi atas permasalah pengelolaan tanah wakaf.Muhammadiyah yang merupakan organisasi Islam tertua yang telah berhasil membuat banyak amal usaha dengan menggunakan wakaf masih belum mampu mengatasi persoalan yang ada.Besarnya wakaf yang di miliki oleh muhammadiyah membutuhkan sebuah analisa untuk membuat klasifikasi wakaf produktif dan non produktif yang mampu memberikan informasi untuk membuat keputusan dalam perencanaan pengelolaan wakaf secara berkesinambungan. Pada penelitian ini Algoritma ID3 digunakan untuk klasifikasi wakaf yang mampu menunjukan kategori produktif dan non produktif dengan menggunakan data yang berasal dari Sistem informasi aset Muhamamdiyah wilayah Yogyakarta. Hasil penelitian memberikan rekomendasi yang di tunjukkan dalam pohon keputusan yang di hasilkan oleh ID3 ,Sehingga bisa simpulkan bahwa untuk pengelolaan wakaf di butuhkan pengelompokan dan klasifikasi tanah produktif dan non produktif dalam upaya membuat rencana pengeloaan wakaf secara profesional. Kata kunci: $\quad$ Sistem Pendukung Keputusan, Algoritma ID3, Data Mining, Sistem Informasi Wakaf, Wakaf Porduktif, Muhammadiyah, Rapidminner
\end{abstract}

\section{PENDAHULUAN}

Wakaf[1] dalam islam merupakan amalan berupa sedekah yang akan dimanfaatkan untuk kepentingan masyarakat dan wakaf tidak bisa di perjual belikan ataupun diberikan kepada ahli warisnya.Indonesia adalah negara muslim terbesar di dunia yang memiliki 50.260.89 Ha .Wakaf memiliki potensi yang besar untuk pengembangan ekonomi berbasis islam untuk menguatkan perekonomian negara .Hal tersebut bisa di lakukan apabila ada pengelolaan wakaf yang profesioanal dan berorentasi pada pengembangan ekonomi secara luas bukan hanya berbasis pada sektor yang berhubungan dengan tempat ibadah saja

Muhammadiyah[2] yang merupkan salah satu organisasi islam indonesia yang memilki kekuatan di bidang ekonomi dan merupakan organisasi yang berpengalaman mengelola organisasi secara modern belum mampu memberikan solusi yang tepat untuk mengatur pengelolaan secara ideal.Masih banyak aset yang tidak dikelola secara baik tapi di sisi lain ada tanah wakaf yang sudah dikelola secara profesional dan menjadi amal usaha seperti rumah sakit dan tempat pendidikan mulai dari tingkat dasar sampai perguruan 
tunggi. Sistem informasi yang di buat belum mampu memberikan solusi dari masalah wakaf yang ada sehingga di butuhkan suatu sistem informasi[3] terbaru yang mampu membuat klasifikasi dan analisa untuk mengetahui wakaf yang dikelola secara produktif dan wakaf non produktif.

Penggunaan tekhnologi informasi yang mampu mengelompokkan data wakaf dan membuat klasifikasikan secara rinci di harapakan mampu memecahkan masalah[4] yang ada .Penelitian ini menggunakan algoritma klasifikasi data mining[5] ID3 yang sangat populer dan memiliki akurasi yang tinggi . Kemampuan Algoritma ID3 untuk membuat pohon keputusan atau ID3[6] secara sederhana dan mudah di pahami akan berguna menganalisa dan memprediksi kategori Wakaf yang sudah dikelola secara baik atau produktif dan yang belum produktif atau non produktif yang di kelola oleh Majelis Wakaf Yogyakarta. Dengan metode klasifikasi data mining algoritma ID3[7] akan dilakukan prediksi dengan pengelompokan data, estimasi dengan memperhatikan kaidah dari asosiasi dari suatu data .

\section{METODE PENELITIAN}

Metode pada penelitian ini meliputi empat tahap yaitu : Tahap pengumpulan data,pembersihan data,transformasi data dan pembentukan Decission Tree atau pohon keputusan dan dokumentasi.

\section{Tahap Pengumpulan Data}

Metode yang dipakai adalah dengan mengumpulkan data yang dipakai dengan cara pengamatan yang dilakukan secara langsung dengan mengambil data dari Sistem Informasi aset Muhammadiyah yang di kelola oleh Majelis wakaf Yogyakarta yang terdiri dari 5 kabupaten dibawah pimpinan daerah Muhammadiyah di wilayah yogyakarta.Peneliti menggunakan data yang sudah di input pada aplikasi majelis wakaf .

\section{Tahap Pembersihan Data}

Untuk mengelompokkan dan menyederhanakan data menjadi data yang lebih bernilai dan membuang data yang tidak diperlukan .Pada tahap ini data akan dikelompokkan

dan disederhanakan menjadi data yang lebih bernilai. Data terdiri dari beberapa atribut dan variable sebagai berikut:

a. Variable yang berhubungan dengan kepemilikan akan di kelompokkan menjadi sebuah atribut dan di tranformasikan menjadi 'Pribadi','Muhammadiyah'.

b. Pengelolaan tanah wakaf bisa di lihat dari atribut penggunaan dan di transformasikan ke Kesehatan,Kantor,Ibadah,Education dan Tanah

Dalam tahap ini dibuat label kreteria pengelolaan wakaf yang akan memberikan nilai keluaran yaitu 'Produktif','Less produktif ' dan 'non produktif'.
3. Tahap Transformasi Data

Akan dilakukan Penyederhaan dan melakukan pengelompokkan data dalam variable output dan variable input.[8]

4. Tahap Pembentukan Pohon Keputusan

Tahap untuk membuat model pohon keputusan dengan algoritma ID3

5. Tahap Dokumentasi

Dokumentasi memakai software Rapidminner untuk mengolah data Wakaf untuk membuat pohon keputusan yang di butuhkan.

\section{HASIL DAN PEMBAHASAN}

\section{A. Tahap Pengumpulan Data}

Dengan mengunakan 855 data dari majelis wakaf yogyakarta dari 5 kabupaten yang telah memasukkan data ke dalam sistem informasi aset muhammadiyah yogyakarta[9]. Data tersebut di gunakan sebagai data uji.

\section{B. Tahap Pembersihan Data}

Dari banyaknya atribut data Wakaf maka di lakukan pembersihan data dengan cara menghapus atribut yang tidak di perlukan yang bertujuan untuk menghasilkan database yang mempunyai nilai dan berguna untuk melakukan proses klasifikasi[10].Dalam melakukan proses pembersihan data ini akan di lakukan penghapusan dari beberapa taribut yang tidak ada hubungannya denga klasifikasi yang akan di lakukan.Beberapa atribut yang di hapus adalah Kode Wilayah,Kode aset,No Sertifikat,Jenis ertifikat,Pemilik Sebelumnya,alamat,desa,luas,cara perolehan,Taksir pasar,fasum,senketa,keterangan,longtitude,latitude

\section{Tahap Transformasi Data}

Pada table 1 di bawah ini adalah hasil dari tahap transformasi data .Hasil Pengumpulan, Pembersihan dan Transformasi Data .

Tabel tersebut bersumber pada data Majelis Wakaf Muhammadiyah Yogyakarta bulan April 2020. Seperti yang terdapat dalam table 1 di bawah ini :

\section{Tabel 1.Transformasi Data}

\begin{tabular}{|l|l|l|}
\hline PEMIUK & PENGGUNAAN & KRETERIA \\
\hline Persyarikatan & Kantor & Produktif \\
\hline Persyarikatan & Kantor & Produktif \\
\hline Persyarikatan & Kantor & Produktif \\
\hline Persyarikatan & Kantor & Produktif \\
\hline Persyarikatan & Kantor & Produktif \\
\hline Persyarikatan & Kantor & Produktif \\
\hline Persyarikatan & Ibadah & Produktif \\
\hline Persyarikatan & Ibadah & less Produktif \\
\hline Persyarikatan & Ibadah & less Produktif \\
\hline Persyarikatan & Pendidikan & Produktif \\
\hline Persyarikatan & Ibadah & less Produktif \\
\hline Persyarikatan & Ibadah & less Produktif \\
\hline Persyarikatan & Ibadah & less Produktif \\
\hline Persyarikatan & Ibadah & less Produktif \\
\hline Persyarikatan & lbadah & less Produktif \\
\hline Persyarikatan & Ibadah & less Produktif \\
\hline Persyarikatan & Ibadah & less Produktif \\
\hline Persyarikatan & Ibadah & less Produktif \\
\hline Persyarikatan & Pendidikan & Produktif \\
\hline Persyarikatan & Ibadah & less Produktif \\
\hline Persyarikatan & Kantor & Produktif \\
\hline Persyarikatan & Ibadah & less Produktif \\
\hline Persyarikatan & Ibadah & less Produktif \\
\hline Persyarikatan & Ibadah & less Produktif \\
\hline Persyarikatan & Kesehatan & Produktif \\
\hline Persyarikatan & sosial & less Produktif \\
\hline Persyarikatan & sosial & less Produktif \\
\hline Persyarikatan & & \\
\hline
\end{tabular}


Pada tahap untuk membuat pohon keputusan di gunakan pemodelan RapidMiner Studio Versi 9.5 sebagai software /alat bantu.. Dengan Algoritma ID3 yang di terapkan mampu menghasilkan design pohon keputusan atau Tree pada Gambar 1.

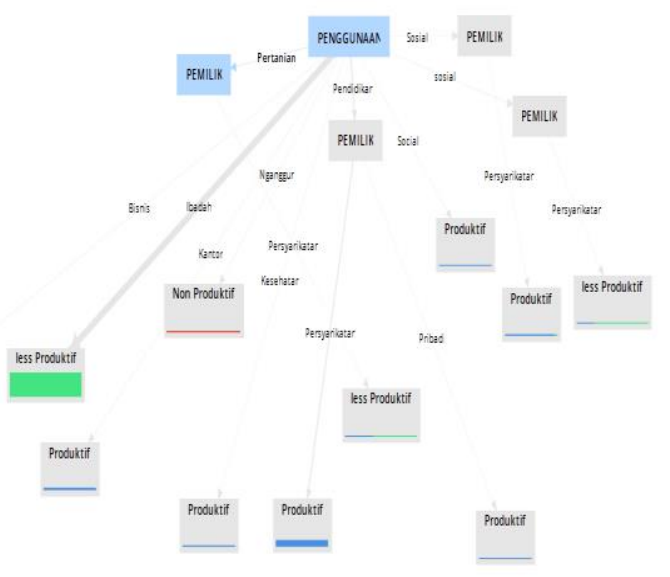

Gambar 1 .Pohon Keputusan Algoritma ID3

Pohon keputusan telah menghasilkan atribut kreteria wakaf dalam pengelolaan dan penggunaannya adalah sebagai berikut:

IF PENGGUNAAN = Bisnis:

Produktif $\{$ Produktif $=13$, less Produktif $=0$, Non Produktif $=0$ \}

ELSE IF PENGGUNAAN = Ibadah:

less Produktif $\{$ Produktif $=0$, less Produktif $=609$, Non Produktif $=0$ \}

ELSE IF PENGGUNAAN = Kantor:

Produktif $\{$ Produktif $=35$, less Produktif $=0$, Non Produktif $=0\}$

ELSE IF PENGGUNAAN = Kesehatan:

Produktif $\{$ Produktif $=9$, less Produktif $=0$, Non Produktif $=0\}$

ELSE IF PENGGUNAAN = Nganggur:

Non Produktif $\{$ Produktif $=0$, less Produktif $=0$, Non Produktif $=13$ \}

ELSE IF PENGGUNAAN = Pendidikan:

Produktif $\{$ Produktif $=150$, less Produktif $=0$, Non Produktif $=0$ \}

ELSE IF PENGGUNAAN = Pertanian

IF PEMILIK = Persyarikatan:

less Produktif $\{$ Produktif $=2$, less Produktif $=3$, Non Produktif $=0$ \}

ENDIF

ELSE IF PENGGUNAAN = Social:

Produktif $\{$ Produktif $=1$, less Produktif $=0$, Non Produktif $=0$ \}

ELSE IF PENGGUNAAN = Sosial

IF PEMILIK = Persyarikatan:

Produktif $\{$ Produktif $=14$, less Produktif $=1$, Non

Produktif $=0$ \}

ENDIF

ELSE IF PENGGUNAAN = sosial
IF PEMILIK = Persyarikatan:

less Produktif $\{$ Produktif $=1$, less Produktif $=3$, Non Produktif $=0$

ENDIF

\section{ENDIF}

Untuk Menentukan akurasi yang di hasilkan dapat dilihat pada tabel 2 berikut.

Tabel 2 . Nilai Akurasi yang di hasilkan oleh Pohon Keputusan

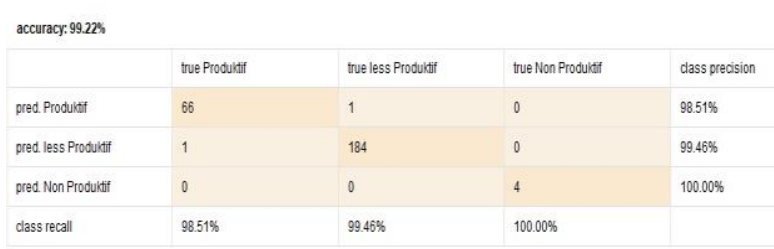

\section{KESIMPULAN}

Klasifikasi wakaf produktif dengan menggunakan Algoritma ID3 telah membuktikan dan mampu memberi informasi pengelolaan wakaf . Penelitian ini telah meghasilkan pohon keputusan dan diperoleh kesimpulan aturan dengan Pengeloaan dengan kreteria Penggunaan Wakaf Produktif ,less produktif dan Non produktif . Tree atau Pohon keputusan telah menghasilkan enam aturan yang sudah melakukan pengelolaan tanah wakaf secara produktif, dengan berbagai atribut pelengkapnya , tiga aturan pengeloaan wakaf dengan kreteria less produktif dan satu aturan pengelolaan yang menunjukan non produktif . Pada penelitian ini di hasilkan nilai akurasi yang akurat dengan diperoleh hasil 99,22\% ,maka kesimpulannya bahwa dalam menentukan pengelolaan tanah wakaf di lingkungan Majelis wakaf yogyakarta belum semuanya di lakukan secara profesional sehingga perlu dikembangkan pengeloaan wakaf menjadi lebih produktif secara keseluruhan.

\section{DAFTAR PUSTAKA}

[1] D. Permaisela, "ANALYSIS OF PRODUCTIVE WAQF PRACTICE AND MANAGEMENT: USING SWOT ANALYSIS METHOD," al-Uqud J. Islam. Econ., 2019. N. Yusra, "MUHAMMADIYAH: GERAKAN PEMBAHARUAN PENDIDIKAN ISLAM," POTENSIA J. Kependidikan Islam, 2018.

[3] S. V. Aleksandrova, M. N. Aleksandrov, and V. A. Vasiliev, "Business Continuity Management System," in Proceedings of the 2018 International Conference "Quality Management, Transport and Information Security, Information Technologies", IT and QM and IS 2018, 2018. 
[4] E. Sugiyarti, K. A. Jasmi, B. Basiron, M. Huda, K. Shankar, and A. Maseleno, "Decision support system of scholarship grantee selection using data mining," Int. J. Pure Appl. Math., 2018.

[5] M. Gupta and S. Minz, "Spatial data classification using decision tree models," in 2017 Conference on Information and Communication Technology (CICT), 2017, pp. $1-5$.

[6] N. Kaewrod and K. Jearanaitanakij, "Improving ID3 algorithm by ignoring minor instances," in 2018 22nd International Computer Science and Engineering Conference, ICSEC 2018, 2018.

[7] K. Kirandeep and P. N. Madan, "Deployment of ID3 decision tree algorithm for placement prediction," Int. J. Trend Sci. Res. Dev., vol. Volume-2, no. Issue-3, pp. 740-744, 2018.

[8] S. Kraidech and K. Jearanaitanakij, "Reducing the depth of ID3 algorithm by combining values from neighboring important attributes," in 2018 22nd International Computer Science and Engineering Conference, ICSEC 2018, 2018.

[9] H. Nashir, Z. Qodir, A. Nurmandi, H. Jubba, and M. Hidayati, "Muhammadiyah's Moderation Stance in the 2019 General Election: Critical Views from Within," $A l$ Jami'ah J. Islam. Stud., 2019.

[10] R. F. Elcullada-Encarnacion, "Academic advising system using data mining method for decision making support," in 2018 4th International Conference on Computer and Technology Applications, ICCTA 2018, 2018. 